\title{
EFFECT OF NITROGEN FERTILIZATION ON PROTEIN CONTENT AND RHEOLOGICAL PROPERTIES OF WINTER WHEAT WHOLEMEAL
}

\author{
Daiga Kunkulberga ${ }^{1}$, Anda Linina ${ }^{2 *}$, Antons Ruza ${ }^{2}$ \\ ${ }^{1}$ Faculty of Food Technology, Latvia University of Life Sciences and Technologies, Rigas iela 22, Jelgava, Latvia \\ ${ }^{2}$ Faculty of Agriculture, Latvia University of Life Sciences and Technologies, Liela iela 2, Jelgava, Latvia e-mail: anda.linina@llu.lv
}

\begin{abstract}
Winter wheat (Triticum aestivum L.) occupies a significant part of the agricultural land in Latvia. High quality winter wheat production is a newsworthy problem nowadays. Growing consumer demand for healthier food is mostly related to wholegrain products in which wholemeal wheat is utilized. The aim of this work is to evaluate the effect of nitrogen fertilization on winter wheat protein content and rheological properties of dough prepared with wholemeal. A field trial was carried out in the study and research farm "Peterlauki" of the Latvia University of Life Sciences and Technologies for three years (2009-2012). The trial included two winter wheat cultivars, like 'Bussard' and 'Zentos' (originating from Germany). Nitrogen was applied in spring after the resumption of vegetative growth. Nitrogen top-dressing rates were as follows: $60,90,120$, and $150 \mathrm{~kg} \mathrm{ha}^{-1}$. Grain crude protein content $(\% \mathrm{~N} \times 5.7)$ was determined by Kjeldahl method. Rheological properties of wholemeal wheat dough were assessed using farinograph, such parameters as water absorption, dough development time, dough stability, degree of softening were tested. Nitrogen fertilization significantly affected protein content and water absorption $(\mathrm{p}<0.05)$. Wholemeal flour prepared with cv 'Bussard' exhibited high stability and can be considered as strong flour. In addition, wholemeal flour prepared with cv 'Zentos' was medium strength flour which can be used in bread baking. The results indicated that application of $120 \mathrm{~kg} \mathrm{ha}^{-1}$ nitrogen fertilizer for cultivar 'Bussard' and $150 \mathrm{~kg} \mathrm{ha}^{-1}$ for cv 'Zentos' can be recommended, to achieve high-quality wholemeal.
\end{abstract}

Keywords: winter wheat, nitrogen fertilization, wholemeal, protein content, rheological properties

\section{Introduction}

Winter wheat (Triticum aestivum L.) is the main cereal crop cultivated in many areas worldwide. Traditional wheat flour is obtained from the endosperm part of the kernel, whereas, wholemeal is obtained by grinding the whole grain. Contrary to endosperm, wholemeal also contains fibre-rich bran, outer coating of the kernel, and wheat germ, the sprouting part of the seed. These parts give wholemeal its distinct flavour, texture and colour, but they also increase the nutritional value of the product because of its natural antioxidants, dietary fibre, B group vitamins etc. (Akhtar et al., 2009).

Climate, fertilization, and cultivar affect baking quality of wheat flavour (Cesevičiené et al., 2012; Koppel, Ingver, 2010; Knapowski, Ralcewicz 2004; Preston et al., 2001). Protein content in wheat grain is related to the strength of dough and it affects bread baking potential (Ahmed, 2015; Linina et al., 2014; Jablonskite-Rašké et al., 2012; Krejčirova et al., 2006; Miš, 2005). Protein accumulation in bread wheat is mostly affected by the climate peculiarities of the particular year and way how nitrogen rates have fluctuated during the growing season (Chope et al., 2015; Krejčirova et al., 2006; Varga et al., 2003). The differences among cultivars are the factors that affect the content of grain protein (Cesevičiené et al., 2012; Linina, Ruza, 2012) as during maturation wheat needs sunlight, moderate humidity and warmth. If the conditions mentioned above are observed, then biological maturity and sufficient rheological and technological properties of the grain will follow (Krejčirova et al., 2006).

Characterization of the rheological properties of dough is a way, which assists in the prediction of processing behaviour and the quality control of baked goods (Koga et al., 2015; Vaicuilute-Funk et al., 2015; Liatukas, Ruzgas, 2012). Lengthy development time, high stability with a small level of softening characterises strong flours, but low stability, short development time, which results in high degree of softening is characteristic for weak flours (Koppel, Ingver, 2010). Therefore, the goal of the paper is to assess the effect of nitrogen fertilization on the protein content of winter wheat and rheological properties of dough prepared with wholemeal.

\section{Materials and Methods}

A field trial was carried out in the study and research farm 'Peterlauki' (latitude: 56 $6^{\circ} 30.658$ ' longitude: $23^{\circ} 41.580^{\prime}$ ) of the Latvia University of Life Sciences and Technologies (LLU) during a three-year period from 2009/2010 to 2011/2012. Soil at the site was Endocalcaric Abruptic Luvisol (Word Reference Base) silt loam. The content of organic matter in the soil was 27-31 $\mathrm{g} \mathrm{kg}^{-1}$, pH KCl 6.6-7.0.

Winter wheat bread cv 'Bussard' and 'Zentos' were sown after black fallow. Sowing was performed in the second ten-day period of September. These cultivars were sown in a plot size of $36 \mathrm{~m}^{2}$ at the rate of 400 germinating seeds per $\mathrm{m}^{2}$. Sowing was performed as a quadruple and treatments were arranged in a randomized block design. Phosphorus $\left(\mathrm{P}_{2} \mathrm{O}_{5}\right)$ and potassium $\left(\mathrm{K}_{2} 0\right)$ fertilizers were applied as $72 \mathrm{~kg} \mathrm{ha}^{-1}$ and $90 \mathrm{~kg} \mathrm{ha}^{-1}$ in autumn, respectively. Nitrogen was applied after resumption of vegetative growth in spring. Nitrogen $(\mathrm{N})$ top-dressing rates were as follows: $60,90,120$ and $150 \mathrm{~kg} \mathrm{ha}^{-1}$, and coded as N60, N90, N120 and N150. All plant protection requirements were fulfilled. Winter wheat was harvested on August 4 in 2010, August 5 in 2011 and August 3 in 2012. Sampling procedure for grain quality evaluation was conducted in accordance with the ICC 101/1 standard.

Protein content and rheological properties of wheat wholemeal were determined each year at the laboratories of Latvia University of Life Sciences and 
Technologies, Faculty of Food Technology. Protein content $(\mathrm{PC}, \% \mathrm{~N} \times 5.7)$ was determined by Kjeldahl method as described in the standard of ICC 105/2 using Kjeltec System 1002 (Foss Tecator AB, Sweden). Grains were milled to wholemeal using a hammer-mill (Laboratory Mill 3100, Perten, Finland) equipped with $0.8 \mathrm{~mm}$ sieve. Farinograph water absorption (WA), dough development time (DDT), dough stability time (ST) and degree of softening (DS12) were determined according to ICC 115/1 standard using Brabender farinograph (Brabender, Germany) equipped with a mixer for $300 \mathrm{~g}$ flour sample.

Experimental data were evaluated using two-factor analysis of variance (ANOVA), Fisher's criterion $(\mathrm{p}<0.05)$, the least significant difference $\left(\operatorname{LSD}_{0.05}\right)$ and the influence of impact factors $\left(\mathrm{n}^{2}\right)$ was also determined. Differences of wholemeal rheological properties between both winter wheat cultivars were determined by t-Test: Two-Sample Assuming Unequal Variance. Correlation analysis between nitrogen fertilization rates and wholemeal rheological properties was carried out.

\section{Results and Discussion}

Protein content is the main quality criterion that influences the properties of baking quality of flour (Koppel, Ingver, 2010). Protein content of $12-13 \%$ is suitable for bread making. The amount of wet gluten, which can be used as an indicator, also affects the baking quality of grains used for bread (Linina, Ruza, 2012).

Protein content in cv 'Bussard' increased from 139.2 to $147.5 \mathrm{~g} \mathrm{~kg}^{-1}$ during the tree year period, while in cv 'Zentos' it increased from 113.2 to $131.2 \mathrm{~g} \mathrm{~kg}^{-1}$, as a result - being much lower $(\mathrm{p}<0.05)$ (Table 1$)$.

Table 1

Protein content $\left(\mathrm{g} \mathrm{kg}^{-1}\right)$ in winter wheat wholemeals depending on nitrogen fertilizer rate

\begin{tabular}{lcc}
\hline \multirow{2}{*}{$\begin{array}{l}\text { Nitrogen (N) } \\
\text { fertilization rate }\end{array}$} & \multicolumn{2}{c}{ Cultivars } \\
\cline { 2 - 3 } N60 & 'Bussard' & 'Zentos' $^{\prime}$ \\
N90 & $139.2^{\mathrm{a}}$ & $113.2^{\mathrm{a}}$ \\
N120 & $139.8^{\mathrm{a}}$ & $118.5^{\mathrm{b}}$ \\
N150 & $147.2^{\mathrm{b}}$ & $127.5^{\mathrm{c}}$ \\
\hline
\end{tabular}

The means marked with the same letter in the same column are not significantly different $(\mathrm{p}>0.05)$.

Grain protein content significantly varies depending on the cultivar and nitrogen fertilization rate as reported previously (Marti et al., 2015; Cesevičiene, 2012; Jablonskité-Raščé et al., 2012; Kučerova, 2005). Marti et al. (2015) reported that the content of albumin, globulin and glutenin proteins in grain gradually increased with the increase of amount of nitrogen. In the current research, nitrogen fertilization significantly $(p<0.05)$ increased grain protein content for both cultivars. The highest protein content was found in the grains of both cultivars grown in the plots treated with N150. Protein content in cv 'Bussard' fertilized at all doses was high and the treatment can be used to improve the quality of grains. The cv 'Zentos' fertilized with the treatments of N120 and N150 could be suggested for bread wheat cultivars.

Dough quality is one of the most significant factors letting to foresee the ultimate bread-making value of winter wheat cultivars (Liatukas, Ruzgas, 2012). The rheological properties of wholemeals were tested by assessing water absorption $\left(\mathrm{g} \mathrm{kg}^{-1}\right)$, dough development time (min), its stability time (min) and its extent of softening (FU-farinograph unit).

Water absorption is an important characteristic for wheat flour (Cesevičiené et al, 2012; Koppel, Ingver, 2010). Water must be mixed into the flour at an optimal stage for the dough to be able to reach the stage, where it has 'optimum development'. In comparison to weak flours, strong wheat flours are able to absorb and preserve more water (Miš, 2005). Therefore, if the dough development time is short, the dough mixing time will also be shorter (Sabovics, Straumite, 2012). According to Kopel and Ingver (2010) an appropriate water absorption value for yeast bread is $550-650 \mathrm{~g} \mathrm{~kg}^{-1}$.

In the present investigation, the water absorption ranges from 707 to $732 \mathrm{~g} \mathrm{~kg}^{-1}$ for $\mathrm{cv}$ 'Bussard' wholemeal and from 677 to $706 \mathrm{~g} \mathrm{~kg}^{-1}$ for cv 'Zentos' (Table 2), thus suggesting that both wholemeals are strong.

Table 2

Water absorption and dough development time in winter wheat wholemeals in relation to nitrogen fertilization rate

\begin{tabular}{lllll}
\hline \multirow{2}{*}{$\begin{array}{c}\text { Nitrogen (N) } \\
\text { fertilization rate }\end{array}$} & \multicolumn{4}{c}{ Cultivars } \\
\cline { 2 - 5 } & 'Bussard' & \multicolumn{2}{c}{ 'Zentos' $^{\prime}$} \\
\cline { 2 - 5 } & WA & DDT & WA & DDT \\
\hline N60 & $707^{\mathrm{a}}$ & $4.56^{\mathrm{a}}$ & $677^{\mathrm{a}}$ & $5.25^{\mathrm{a}}$ \\
N90 & $716^{\mathrm{b}}$ & $4.47^{\mathrm{a}}$ & $675^{\mathrm{a}}$ & $5.85^{\mathrm{b}}$ \\
N120 & $727^{\mathrm{c}}$ & $4.83^{\mathrm{b}}$ & $690^{\mathrm{b}}$ & $5.98^{\mathrm{c}}$ \\
N150 & $732^{\mathrm{c}}$ & $5.16^{\mathrm{c}}$ & $706^{\mathrm{c}}$ & $6.39^{\mathrm{d}}$ \\
\hline
\end{tabular}

$\overline{\text { WA - water absorption }\left(\mathrm{g} \mathrm{kg}^{-1}\right) \text {; DDT - dough development }}$ time ( $\mathrm{min})$.

The means marked with the identical letter in the same column do not differ significantly $(\mathrm{p}>0.05)$.

Water absorptions in wheat flours varies depending on the cultivars (Marti et al., 2015), and in our investigation, wholemeal prepared from cv 'Bussard' had a much higher water absorption level $(\mathrm{p}<0.05)$. In the report of Vaiciulyte-Funk et al. (2015), water absorption of refined wheat flour for cv 'Zentos' was $607 \mathrm{~g} \mathrm{~kg}^{-1}$, and for cv Portal - $656 \mathrm{~g} \mathrm{~kg}^{-1}$. Kalnina et al. (2015) showed that wholemeal flour absorbs a higher amount of water, the tested cv 'Zentos' showed a water absorption of $692 \mathrm{~g} \mathrm{~kg}^{-1}$ as similar results can also be seen in this study. Cesevičiené et al. (2012) found that wheat flour obtained from winter wheat grown in conventional production (nitrogen fertilization of $120 \mathrm{~kg} \mathrm{ha}^{-1}$ ) had water absorption values range from 594 to $627 \mathrm{~g} \mathrm{~kg}^{-1}$, while water absorption in flours from organic production (without nitrogen fertilization) were within the range of 573 to $603 \mathrm{~g} \mathrm{~kg}^{-1}$. An increase in nitrogen fertilization significantly increases protein content and water absorption 
(Miš et al., 2005; Wooding et al., 2000) and these data are in agreement with our findings.

Dough development time (DDT) shows the relative strength of the dough and may also reflect on the degree of water absorption. Dough development time of the two cultivars was high, DDT values of cv 'Bussard' and cv "Zentos' ranged from 4.56 to $5.16 \mathrm{~min}$ and 5.25 to 6.39 min, rescpectively (Table 2). Kalnina et al. (2015) had similar results by discovering that DDT value of wholemeal cv 'Zentos' was $6.30 \mathrm{~min}$, while Cesevičiené et al. (2012) showed 2.4 min DDT for refined flour of the same cultivar. The excessively high DDT could be caused by the presence of higher moisture content of the bran particles in wholemeal, where bran particles may have delayed dough gluten development (Haridas Rao et al., 1989).

When wheat was treated with higher doses of nitrogen fertilization, its wholemeal significantly extended DDT as reported by Cesevičiene et al., (2012). Dough development time is also influenced by protein content of wheat flour (Vaiciulyte-Funk et al., 2015). This study also proved it.

Stability time of the dough (ST) is a very important factor which affects the possible level of fermentation and mechanical stress the dough can be exposed to. Good quality dough has a stability from 4 to $12 \mathrm{~min}$ which is defined as a strong flour (Kopel, Ingver, 2010). Dough stability is a significant indicator in determining flour strength by observing the quantity and quality of dough protein content (Kučerova, 2005). In our investigation, it was found that dough stability of cv 'Bussard' and cv 'Zentos' wholemeal was within the range of 9.31-10.41 $\mathrm{min}$ and 6.89-7.08 $\mathrm{min}$, respectively, when an increased dose of nitrogen fertilization (N120 and N150) was applied (Table 3).

Similar outcomes were found in the study by Varga et al. (2003). Wholemeal obtained from cv 'Bussard' had a significantly higher dough stability time than that of the cv 'Zentos' $(\mathrm{p}<0.05)$, however, both cultivar wholemeals were strong. Flour stability is related with cultivar properties, which confirms the reports of Kopell and Ingver (2010) published before. Water absorption and mixing properties of wholemeal dough could be improved by increasing wheat protein content. Softening degree (DS12) is the distance from the centre of the curve to $500 \mathrm{FU}$ (farinograph units) consistency line after 12 minutes from the end of the dough development time. Dough mixing quality is taken as satisfactory when the softening value is less than 70 FU (Williams, 1997). Degree of softening of cv 'Bussard' ranges from 21.18 to $26.78 \mathrm{FU}$ and that of wholemeal cv 'Zentos' ( $\mathrm{p}<0.05$ ), however, both cultivar wholemeals were' cultivar from 37.4 to $50.2 \mathrm{FU}$ (Table 3).

Genetic characteristics of cultivar influence dough softening (Liatukas, Ruzgas, 2012), it was also confirmed in our study. When nitrogen application was increased during the growth of cv 'Zentos', $(\mathrm{p}<0.05)$, however, both cultivar wholemeals were the degree of softening values of its wholemeal tended to decline, this was in agreement with earlier reports (Cesevičiene et al., 2012). Conversely, wholemeal cv 'Bussard' fluctuated with the increase of nitrogen fertilization level.

Table 3

Dough stability time and degree of softening of winter wheat wholemeals depending on nitrogen fertilization rate

\begin{tabular}{lcccc}
\hline & \multicolumn{4}{c}{ Cultivars } \\
\cline { 2 - 5 } Nitrogen & \multicolumn{2}{c}{ 'Bussard' } & \multicolumn{2}{c}{ Zentos' $^{\prime}$} \\
\cline { 2 - 5 } Fertilizer (N) & ST & DS12 & ST & DS12 \\
\hline N60 & $7.84^{\mathrm{a}}$ & $21.18^{\mathrm{c}}$ & $6.34^{\mathrm{a}}$ & $50.2^{\mathrm{c}}$ \\
N90 & $8.49^{\mathrm{b}}$ & $25.13^{\mathrm{b}}$ & $6.77^{\mathrm{b}}$ & $44.6^{\mathrm{b}}$ \\
N120 & $9.31^{\mathrm{c}}$ & $22.28^{\mathrm{a}}$ & $6.89^{\mathrm{c}}$ & $40.1^{\mathrm{a}}$ \\
N150 & $10.41^{\mathrm{d}}$ & $26.78^{\mathrm{b}}$ & $7.08^{\mathrm{d}}$ & $37.4^{\mathrm{a}}$ \\
\hline
\end{tabular}

ST - dough stability time (min), DS12 - dough degree of softening value after $12 \mathrm{~min}$ (FU - farinograph units).

The means marked with the identical letter in the same column are not significantly different ( $\mathrm{p}>0.05)$.

By Fisher's criteria, nitrogen fertilizer and year (weather conditions in trial years), and interaction of nitrogen fertilizer $\times$ year significantly $(\mathrm{p}<0.05)$ impacted $\left(\mathrm{y}^{2}\right)$ the protein content of wholemeal and such rheological parameters as water absorption, time of dough development and stability as well as softening degree (Table 4).

Table 4

Impact factors $\left(\mathrm{y}^{2}\right)$ of winter wheat wholemeal quality indices, $(\%)$

\begin{tabular}{lccccc}
\hline \multirow{2}{*}{$\begin{array}{l}\text { Source of } \\
\text { variation }\end{array}$} & PC & WA & DDT & ST & DS12 \\
\cline { 2 - 6 } $\mathrm{N}$ & 7.6 & 39.9 & 14.8 & 28.5 & 10.6 \\
$\mathrm{Y}$ & 87.3 & 39.1 & 77.3 & 55.9 & 58.1 \\
$\mathrm{~N} \times \mathrm{Y}$ & 4.4 & 17.9. & 7.1 & 15.2 & 29.1 \\
\hline \multicolumn{5}{c}{ cv 'Zentos' $^{\prime}$ 'Bussard' } \\
\hline $\mathrm{N}$ & 19.8 & 38.5 & 38.3 & 3 & 22.8 \\
Year & 78.8 & 43.5 & 45.2 & 94 & 53.1 \\
$\mathrm{~N} \times \mathrm{Y}$ & 1.1 & $10.7^{*}$ & 15.1 & 2.9 & 20.5 \\
\hline $\mathrm{N}$ - nitrogen fertilizer, Y - year, N NY - nitrogen and year \\
interaction, PC - protein content, WA - water absorption, \\
DDT - dough development time, ST - dough & stability, \\
DS12 - degree of softening, * - not significant
\end{tabular}

Winter wheat grain protein content depended on year by $87.3 \%$ (cv 'Bussard') and $78.8 \%$ (cv 'Zentos'), while the influence of nitrogen fertilizer was also remarkable $7.6 \%$ for $\mathrm{cv}$ 'Bussard' and $19.8 \%$ for cv 'Zentos'. The lowest impact was found in the interaction of nitrogen fertilizer $\times$ year.

Nitrogen fertilizer significantly affected water absorption values of wholemeals. Conversely, the lower impact was found on dough mixing properties. Koppel and Ingver (2010) found influence of the year on protein content, water absorption and dough stability time as the most remarkable result, a total of 15 winter and 14 spring wheat cultivars were harvested and tested in Estonia in the years between 2004-2007. The accumulation of protein in wheat kernels is better if the 
weather is warmer, there is more sunlight and less moisture (Cesevičiene et al., 2012).

In 2010 and 2011, the average temperature from April to July was $>+14{ }^{\circ} \mathrm{C}$, which led to more favourable conditions for protein synthesis in grain, while cool and rainy weather caused adverse effect during grain filling and maturation period in the year of 2012. The two cultivars had the lowest protein content $\sin 2012$.

A statistically important moderate positive correlation was observed between nitrogen fertilizer and water absorption value of wholemeal $\mathrm{cv}$ 'Bussard $(\mathrm{r}=0.633)$ and $\mathrm{cv}$ Zentos' $^{\prime}(\mathrm{r}=0.592)\left(\mathrm{n}=12, \mathrm{r}_{0.05}=0.576\right)$. Dough development time for cv Zentos exhibited moderate positive relationship with nitrogen fertilizer $(r=0.608)$.

\section{Conclusions}

By increasing nitrogen fertilizer rate, the grain technological properties of both winter wheat cultivars were improved significantly. 'Bussard' cultivar had higher values of crude protein content than cv 'Zentos'. Wholemeal of cv 'Bussard' can be considered as strong flour, with a high mixing value with weaker flour, but the wholemeal of cv 'Zentos' was medium strong and it could be used for direct bread baking. In order to achieve good grain quality for producing wholemeal, $120 \mathrm{~kg} \mathrm{ha}^{-1}$ of nitrogen fertilizer should be used for cv 'Bussard', and $150 \mathrm{~kg} \mathrm{ha}^{-1}$ for cv 'Zentos.'

\section{Acknowledgement}

The research has been prepared within the framework of the State Research Programme "Sustainable use of local resources (earth, food, and transport) - new products and technologies (NatRes)" Project No. 3. Sustainable use of local agricultural resources for development of high nutritive value food products (Food)".

\section{References}

1. Ahmed R., Ali R., Khan M.S., Moin M., Kazmi S.I., Sayeed S. A. (2015) Comparative study on the physicochemical and rheological parameters of soft wheat flour obtained from three countries. American Journal Food Science and Nutrition Research, Vol. 2 (3), p. 89-93.

2. Akhtar S., Anjum F.M., Rehman S.U., Sheikh M.A. (2009) Effect or mineral fortification on rheological properties of whole wheat flour. Journal of Texture Studies, Vol. 40, p. 51-65.

3. Ceseviciené J., Slepetiene A., Leistrumaite A., Ruzgas V. (2012) Effects of organic and conventional technological properties. Journal of the Science of Food and Agriculture, Vol. 92 (14), p. 2811-2818.

4. Chope G.A., Wan Y., Penson S.P., Bhandari D.G., Powers S.J., Shewry P.R., Hawkesford M.J. (2015) Effect of genotype, season, and nitrogen nutrition on gene expression and protein accumulation in wheat grain. Journal of Agriculture and Food Chemistry, Vol. 62, p. 4399-4407.

5. Haridas Rao P., Leelavathi K., Shurpalekar S.R. (1989) Effect of damaged starch on the chapatti-making quality of whole wheat flour. Cereal Chemistry. Vol. 66 (4), p. 329-333.
6. Jablonskité-Raščé D., Maikšteniené S., Mankevičiené A (2012) Evaluation of productivity and quality of common wheat (Triticum aestivum L.) and spelt (Triticum spelta L.) in relation to nutrition conditions. ZemdirbysteAgriculture, Vol. 100 (1), p. 45-56.

7. Kalnina S., Rakcejeva T., Kunkulberga, D., Galoburda R. (2015) Rheological properties of whole wheat and whole triticale flour blends for pasta production. Agronomy Research, Vol. 13 (4), p. 948-955.

8. Knapowski T., Ralcewicz M. (2004) Evaluation of qualitative features of Mikon cultivar winter wheat grain and flour depending on selected agronomic factors. Electronic Journal of Polish Agricultural Universities, 7 (1). [accessed on 08.01.2019.]. Available: http://www.ejpau.media.pl/volume7/issue1/agronomy/art $-01 . h t m l$

9. Koga S., Böcker U., Moldestad A., Tosi P., Shewry P.R., Mosleth E.F., Uhlen A.K. (2015) Influence of temperature on the composition and polymerization of gluten proteins during grain filling in spring wheat (Triticum aestivum $\mathrm{L}$ ). Journal of Cereal Science, Vol. 65, p. 108-113.

10. Koppel R., Ingver, A. (2010). Stability and predictability of baking quality of winter wheat. Agronomy Research, Vol. 8 (III), p. 637-644.

11. Krejčirova L., Capouchova I., Petr J., Bicanova E., Kvapil R. (2006) Protein composition and quality of winter wheat from organic and conventional farming. ZemdirbysteAgriculture, Vol. 93 (4), p. 285-296.

12. Kučerova J. (2005). The effect of sites and years on the technological quality of winter wheat grain. Plant, Soil and Environment, Vol. 51 (3), p. 101-109.

13. Liatukas Ž., Ruzgas V., Razbadauskiené K. Brazauskas G., Koppel R. (2012) Winter wheat cultivars 'Kovas DS', 'Zunda DS', 'Vikaras DS', 'Kaskada DS' for high input farming: development and characterization. Zemdirbyste-Agriculture, Vol. 99 (3), p. 225-264.

14. Linina A., Ruza A. (2012) Cultivar and nitrogen fertilizer effects on fresh and stored winter wheat grain quality indices. Proceedings of Latvian Academy of Sciences, Section B, Vol. 66 (4/5), p. 177-184.

15. Linina A., Kunkulberga D., Ruza A. (2014) Influence of nitrogen fertiliser on winter wheat wholemeal rheological properties. Proceedings of Latvian Academy of Sciences, Section B, Vol. 68 (3/4), p.158-165.

16. Marti A., Ulrici A., Foca G., Quaglia L., Pagani, M.A. (2015) Characterization of common wheat flours (Triticum aestivum L) through multivariate analysis of conventional rheological parameters and gluten peak test indices. LWT-Food Science and Technology, Vol. 64, p. $95-103$.

17. Miš A. (2005) Influence of chosen factors on water absorption and rheological properties of gluten of bread wheat (Triticum aestivum L), Acta Agrophysica, Vol. 128 (8), p. 1-120.

18. Preston K.R., Hucl P., Townley-Smith T.F., Dexter J.E., Williams P.C., Stevenson S.G. (2001) Effects of cultivar and environment on farinograph and Canadian short process mixing properties of Canada western red spring wheat. Canadian Journal of Plant Science, Vol. 81 (3), p. 391-398.

19. Sabovics M., Straumite E. (2012) Rheological properties of triticale (Triticosecale Wittmack) flour blends dough. In: Annual 18 International conference: Research for Rural Development, Conference Proceeding. Vol. 1, p. 143-148.

20. Vaiciulute-Funk L., Joudeikiene G., Bartkiene, E. (2015) The relationship between wheat baking properties, specific 
high molecular weight glutenin components and characteristic of varieties. Zemdirbyste-Agriculture, Vol. 102 (2), p. 229-238.

21. Varga B., Svecnjak Z., Jurkovic Z., Kovacevic J., Jukic, Z. (2003) Wheat grain and flour quality as affected by cropping intensity. Food Technology and Biotechnology, Vol. 41 (4), p. 321-329.

22. Williams P. (1997) Variety development and quality control of wheat in Canada: Characterization by functionality. In: International Japanese conference on Near-Infrared Reflectance, Proceedings of International Conference, Japan, p. 1020-1044.

23. Wooding A.R., Kavale S., MacRitche, Stooddard F. L., Wallace A. (2000) Effect of nitrogen and sulfur fertilizer on protein composition, mixing requirements, and dough strength of flour wheat cultivars. Cereal Chemistry, Vol. 77 (6), p. 798-807. 